\title{
THE PUERTO RICAN FORII OF THE BROAD-WINGED HAWK
}

By Stuart T. Danforth and J. Adger Smyth.

The Broad-winged Hawk is at present a very rare bird in Puerto Rico, there being no certain record of specimens having been obtained there until now. Therefore the capture of a specimen by one of the writers is of more than ordinary interest, especially as it appears to represent a race hitherto unknown to science, which may be known as

\section{Buteo platypterus brunnescens, subsp. nov.}

Type.-Adult female, ovary well developed, coll. S. T. Danforth 1890, collected on El Yunque Mountain, Puerto Rico, August 2, 1935, by J. Adger Smyth.

Subspecific characters.-Darker than any other known form of B. platypterus. Smaller than typical B. p. platypterus; larger than B. p. insulicola or B. p. riviert.

Measurements of type.-Length (in flesh) 387.5; extent 856.2; wing (chord) 264.5; tail 159.0; culmen from cere 20.8; tarsus 56.3 millimeters.

Remarks.-The upper parts in general of the new form are slightly darker than fuscous black. The underparts are tawny olive so heavy barred with mummy brown that the bars are nearly confluent on the throat and breast.

The measurements of some female specimens of Broad-winged Hawks from the Lesser Antilles in the Danforth collection are given for comparison: One female B. p. insulicola from Antigua, length (in flesh) 394; extent 849; wing 251.8; tail 151.5; culmen from cere 1915; tarsus $56.4 \mathrm{~mm}$. Two female $B$. p. rivieri from St. Lucia, length in flesh (one) 375; extent (one) 825; wing 246.6265.8 (256.2) ; tail 157.9-159.0 (158.4); culmen from cere 18.919.3 (19.1) ; tarsus 54.2-54.6 (54.4). Three female B. p. antillarum from Grenada, length (in flesh) 390.0-410.0 (396.6) ; extent 875.0 919.0 (890.3), wing 260.6-272.6 (267.4); tail 153.8-166.6 (158.9); culmen from cere 19.3-20.5 (19.9); tarsus 54.0-57.0 (55.4) mm.

It might be remarked that from the material at hand $B . p$. rivieri does not appear to be a well marked form, although birds from St. Lucia average somewhat smaller and darker than those from Grenada. No Cuban examples were seen, but Riley (Auk, 1908, p. 271) found 
only slight differences in color between $B . p$. antillarum and Cuban birds, noting that the principal difference was in the smaller size of antillarum, and could not distinguish it as regards colors from North American birds. As the present specimen from Puerto Rico is so decidedly darker than any specimens seen from North America or the Lesser Antilles, we have no hesitation in describing it as a new form. 